\title{
Irregular Anatomical Features of Wood as an Aid in Silviculture*
}

\section{GLERUM}

Ministry of Natural Resources,

Division of Forests,

Forest Research Branch,

Maple, Ontario LOJ IÉO

\section{Abstract \\ Anatomical irregularities in xylem caused by frost, drought and insect attack are described. The value of these irregularities as a diagnostic tool for silviculture and in determining the history of a tree is discussed.}

\section{Résumé}

L'auteur parle de certaines irrégularités anatomiques dues au froid, à la sécheresse et aux attaques d'insectes. II discute de l'intérêt de ces défauts en tant que diagnose pour la sylviculture et I'historique de l'arbre.
The anatomy of the xylem (wood) can be considered as a permanent record of a tree's life. The favorable and adverse conditions that have occurred during the life of a tree will be recorded in the wood. Each type of adverse condition will cause a characteristic type of irregularity. Therefore, these irregularities are useful in determining the history of a tree and the history of a stand of trees. This information can be helpful in deciding what silvicultural practices to apply to the area under investigation. My purpose here is twofold: to draw attention to the value of looking at anatomical features of the xylem and to give a brief outline of the most common anatomical irregularities.

Adversities such as insect and fungal attack, frost, drought and lightning, will cause anatomical irregularities. Several investigators (Day and Peace 1934; Harris 1934; Kramer and Kozlowski 1960; Rhoads 1923) have pointed out that these adversities cause similar damage. However, my studies (Glerum and Farrar 1966) on the structure and development of frost rings have led me to suspect that although other adversities cause somewhat similar damage as frost, distinct differences should occur.

A frost ring (see Fig. 1,2a,b) generally consists of a band of underlignified tracheids followed by a band of partially crushed tracheids and one of totally collapsed or crushed tracheids, which in turn is followed by isodiametric parenchyma cells and abnormal tracheids. Another feature is the lateral expansion and displacement of the rays. The distinctness of these various features will vary considerably because they depend on the stage of cambial activity at the time of the frost, and also on the intensity of the frost.

Drought is supposed to cause damage similar to that caused by frost (Day and Peace 1934; Parker 1963). Granted, when trees are subjected to drought rapidly, underlignified and distorted cells are produced, which are similar to some of the cells in frost rings (Glerum, unpublished). However, under natural stand conditions most droughts will occur gradually, while frosts always occur rapidly. Therefore, it can be expected that their effects on the developing xylem will be different. There is sufficient evidence to suggest 
that under natural conditions, drought rings in general are made up of cells similar in shape to those of the latewood, as illustrated in Fig. 2a and $2 \mathrm{~b}$. These are cells with narrow radial diameters (Dobbs 1953; Doley 1970; Glerum 1970; Harris 1955; Larson 1963). Furthermore, droughts generally occur later in the growing season than frosts, which would cause drought rings to be situated further on in the annual growth layer than frost rings.

Insect damage such as that caused by white pine weevil (Pissodes strobi Peck) shows up as a false ring but this ring remains rather close to the top of the tree, near the place of attack, instead of extending all the way down the stem. Furthermore, such a ring tends to consist mainly of a band of collapsed tracheids and some abnormal tracheids. However, one of the characteristic features of the frost ring is absent, namely the band of underlignified tracheids that precedes the band of collapsed tracheids. Defoliating insects such as the European pine sawfly (Neodiprion sertifer Geoff.) will cause a band of underlignified tracheids providing the foliage from all previous years is removed. Under these circumstances the following year's growth is also drastically reduced, as illustrated in Fig. $3 a$ and $3 b$ (Balatinecz 1966).

Planes of weakness in the wood, which can lead to ring shake will be caused by some false rings. This is of no practical importance in rela- tion to frost rings because they are generally confined to small trees (up to $3 \mathrm{~m}$ in height and $10 \mathrm{~cm}$ in diameter). However, a plane of weakness such as an unlignified band of tracheids caused by defoliation, which could occur during the pole stage of a conifer, will definitely have important practical implications.

The diagnostic values of the various false rings, but especially those of frost rings, are important. Frost rings can be used for determining differences in frost hardiness between different strains and provenances (Dietrichson 1967; Fowler and Heimburger 1969; Venn 1970). Frost rings have been used for some time in absolute dating and cross-dating, which are useful methods in archaeology and climatology (Bailey 1925; Glock et al. 1960).

Another diagnostic aspect of frost rings, usually overlooked, is their value in providing indications of microclimatic conditions that prevailed during the early stages of the stand. The structure of the frost ring and its horizontal position in the annual layer will give an indication of the intensity or the frost and the time when it occurred. It will also reflect the degree of cambial activity at the time of the frost. If frost rings occur in several annual growth layers then the stand is in a frost-susceptible area and subject to extreme microclimatic fluctuation. Thus the presence of frost rings might help to explain the relative development of parts of one stand or of adjacent
Figure 1. A frost ring (arrow) in the xylem of a white spruce stem caused by a light frost in late June. The distinct line of dark material is the layer of crushed cells, below which are deformed and incompletely lignified tracheids. Above this layer are a few parenchyma cells and some abnormal tracheids. Note the lateral expansion and displacement of the rays. $70 \mathrm{X}$.

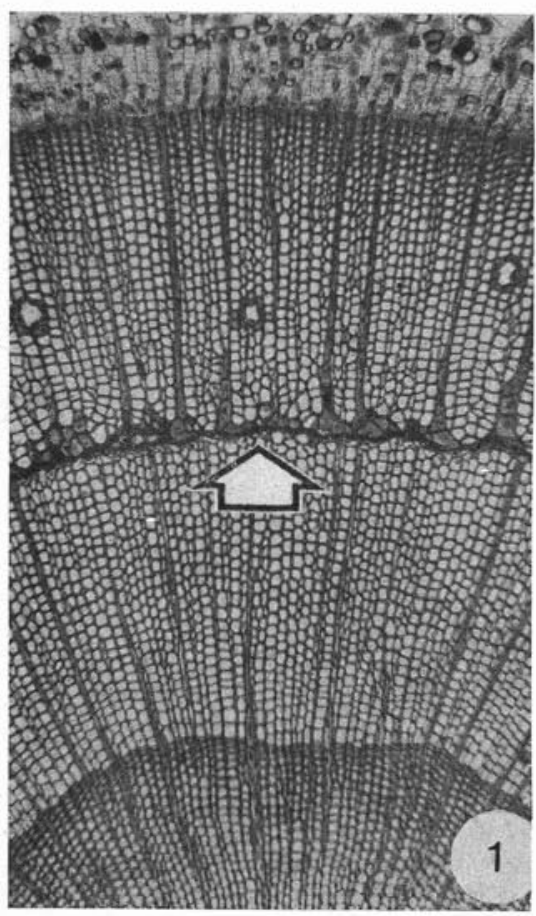

Figure 2a. A drought ring in the xylem of a white pine towards the end of the annual growth layer (arrow 1) Note also (arrow 2) the frost rings at the boundaries of the annual growth layers. 25X.

\begin{abstract}
Figure 2b. The drought and frost ring (Fig. 2a) at higher magnification. Note the narrow radial diameters of the tracheids in the drought ring (arrow 1). The frost ring (arrow 2) was caused by a severe frost early in the spring just at the time when cambial activity had begun. The band of crushed cells is nearly absent but there are parenchyma cells and many abnormal tracheids. 70X.
\end{abstract}
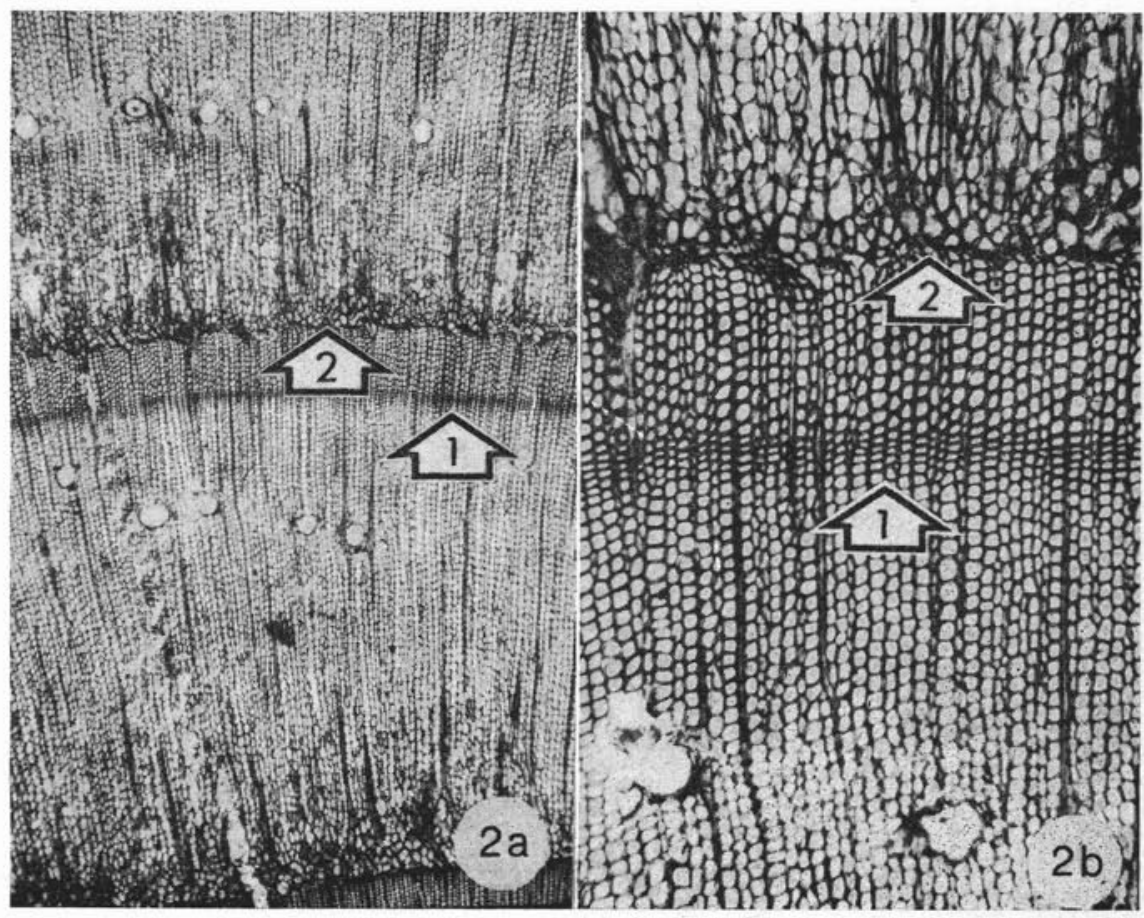
stands, depending on the situation of one stand in relation to the other. The same applies to the other types of false rings. This information together with other relevant data, should facilitate the selection of a suitable silvicultural treatment for an area.

It is important to consider the point of sampling when false rings are to be used for diagnostic purposes. Since frost rings are generally confined to small trees, they will occur near the center of older trees, therefore the sampling will have to be done somewhere from $30 \mathrm{~cm}$ above the ground to a height of 2 to $3 \mathrm{~m}$ and close to the pith. In contrast, drought rings generally occur all the way up the annual growth layer, consequently the sampling can be done at any height. In the case of abnormal rings caused by defoliation the band of unlignified to underlignified tracheids was either absent or difficult to detect near the top of the tree, but became very distinct somewhere below the crown and remained distinct all the way down to stump level (Glerum, unpublished). Therefore the point of sampling for this type of ring should be well below the crown. In general the best point of sampling for most anatomical irregularities is just above stump level.

Many difficulties will be encountered when looking at anatomical irregularities such as the variability of the false ring and discontinuous rings. Nevertheless, I hope that this paper will stimulate interest in the diagnostic value of anatomical irregularities as a silvicultural tool and thus strengthening our silvicultural practices.

\section{Acknowledgments}

Professor J.J. Balatinecz, Faculty of Forestry, University of Toronto supplied the larch sections and Miss Jean Robinson took the photomicrographs.

\section{References}

Bailey, I.W. 1925. The spruce budworm biocoenose. I. Frost rings as indicators of the chronology of specific biological events. Bot. Gaz. 80:93-101.

Balatinecz, J.J. 1966. The physiological mechanisms of earlywood-latewood differentiation in larch. PhD. Thesis, University of Toronto, Toronto, Ontario.

Day, W.R. and T.R. Peace. 1934. The experimental production of the diagnosis of frost injury on forest trees. Oxf. For. Mem. 16:1-60.

Dietrichson, J. 1967. Climatic damage, growth rhythm and height development. Meddr. norske Skogfors. Ves. 21:145-158.

Dobbs, C.G. 1953. A study of growth rings in trees. III. Forestry 26:97-110.

Doley, D. 1970. Effects of simulated drought on shoot development in Liriodendron seedlings. New Phytol. 69:655673.

Fowler, D.P. and C. Heimburger. 1969. Geographic variation in eastern white pine, 7-year results in Ontario. Silv. Genet. 18:123-129.

Glerum, C. 1970. Drought ring formation in conifers. For. Sci. 16:246-248.

Glerum, C. and J.L. Farrar. 1966. Frost ring formation in the stems of some coniferous species. Can. J. Bot. 44:879-886.

Glock, W.S., R.A. Studhalter and S.R. Agerter. 1960. Classification and multiplicity of growth layers in the branches of trees at the extreme lower forest border. Smithsonian Misc. Coll. 140 (1) Publ. 4421.

Harris, E.H.M. 1955. The effect of rainfall on the latewood of Scots pine and other conifers in East Anglia. Forestry 28:136-140.

Harris, H.A. 1934. Frost ring formation in some winterinjured deciduous trees and shrubs. Amer. J. Bot. 21:485-498.

Kramer, P.J. and T.T. Kozlowski. 1960. Physiology of trees. McGraw Hill Book Co., Inc., N.Y.

Larson, P.R. 1963. The indirect effect of drought on tracheid diameter in red pine. For. Sci. 9:52-62.

Parker, J. 1963. Cold resistance of woody plants. Bot. Rev. 29:123-201.

Rhoads, A.S. 1923. The formation and pathological anatomy of frost rings in conifers injured by late frosts. U.S. Dep. Agr. Bull. 1131.

Venn, K. 1970. Studies on a particular dieback of terminal shoots of Pinus sylvestris L. Meddr. norske Skogfors. Ves. 27:510-536.

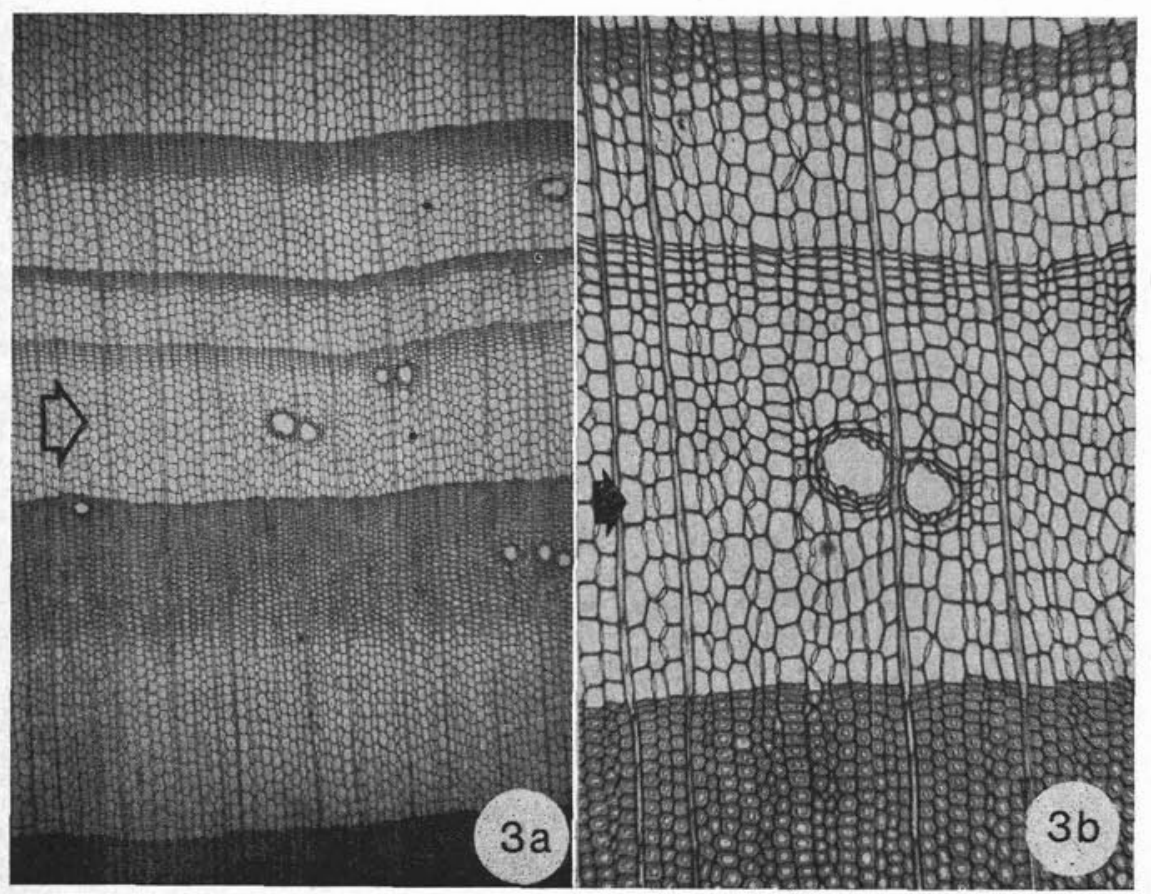

Figure 3a. The effect of defoliation in a larch tree (arrow). The annual growth layer has been reduced and so have the subsequent two growth layers. The growth layer formed during the defoliation year (arrow) has a marked reduction in latewood tracheids, which have thinner cell walls than normal. 25X.

Figure $\mathbf{3 b}$. The effect of defoliation in larch (Fig. 3a) at higher magnification. Here the underlignified tracheids and the thin-walled latewood tracheids are clearly evident. 70X. 